CLINICAL STUDY

\title{
Antipituitary antibodies after traumatic brain injury: is head trauma-induced pituitary dysfunction associated with autoimmunity?
}

Fatih Tanriverdi*, Annamaria De Bellis ${ }^{1, *}$ Antonio Bizzarro ${ }^{2}$, Antonio Agostino Sinisi ${ }^{1}$, Giuseppe Bellastella ${ }^{1}$, Elena Pane ${ }^{1}$, Antonio Bellastella ${ }^{1}$, Kursad Unluhizarci, Ahmet Selcuklu ${ }^{3}$, Felipe F Casanueva ${ }^{4}$ and Fahrettin Kelestimur

Department of Endocrinology, Erciyes University Medical School, 38039 Kayseri, Turkey, ${ }^{1}$ Chair of Endocrinology and ${ }^{2}$ Chair of Immunology, Second University of Naples, Via S. Pansini, 5, 80131 Naples, Italy, ${ }^{3}$ Department of Neurosurgery, Erciyes University Medical School, Kayseri, Turkey and ${ }^{4}$ Department of Medicine School of Medicine and Complejo Hospitalario Universitario de Santiago, Santiago de Compostela University, Santiago de Compostela, Spain

(Correspondence should be addressed to F Kelestimur; Email: fktimur@erciyes.edu.tr)

${ }^{*}$ F Tanriverdi and A De Bellis contributed equally to this work

\begin{abstract}
Objective: Traumatic brain injury (TBI) is a devastating public health problem that may result in hypopituitarism. However, the mechanisms responsible for hypothalamic-pituitary dysfunction due to TBI are still unclear. Although the antibodies against neurons have been demonstrated in injured animal studies, investigations regarding the occurrence of antipituitary antibodies (APAs) in patients with TBI are lacking in the literature. In order to investigate whether autoimmune mechanisms could play a role in the pituitary dysfunction after TBI, we have planned this study aimed at investigating the presence of APA at the third year of TBI and association between the TBI-induced hypopituitarism and APA.

Patients and design: Twenty-nine (25 males and 4 females; age $36.5 \pm 2.3$ years) patients who had completed a 3-year follow-up after TBI were included in the present study. APA and pituitary function were evaluated in all the patients 3 years after TBI; moreover, APAs were tested also in sera of 60 age-/sexmatched normal controls. The APAs were investigated by an indirect immunofluorescence method. Results: APAs were detected in 13 out of the 29 TBI patients (44.8\%), but in none of the normal controls. Pituitary dysfunction development ratio was significantly higher in APA-positive patients (46.2\%) when compared with APA-negative ones $(12.5 \% ; P=0.04)$. There was a significant association between APA positivity and hypopituitarism due to TBI (odds ratio: $2.25,95 \%$ confidence intervals 1.1-4.6). Moreover, there was a significant positive correlation $(r=0.74, P=0.004)$ between APA titer ratio and peak GH response to GHRH $+\mathrm{GH}$ related peptide (GHRP)- 6 test, suggesting that high APA titers were associated with low GH response to GHRH + GHRP-6 test.

Conclusions: This study shows for the first time the presence of the APA in TBI patients 3 years after head trauma. Moreover, present investigation indicates preliminary evidence that APA may be associated with the development of TBI-induced pituitary dysfunction, thus suggesting that autoimmunity may contribute in the development of TBI-induced hypopituitarism. The presence of the association between APA and TBIinduced hypopituitarism may provide a new point of view in this field and promote further clinical and experimental studies.
\end{abstract}

European Journal of Endocrinology 159 7-13

\section{Introduction}

Traumatic brain injury (TBI) is a devastating public health problem and current data clearly establish that it may result in pituitary dysfunction. After TBI, $20-50 \%$ of patients have been reported to have some degrees of pituitary dysfunction (1-4). Growth hormone (GH) is the most frequently affected pituitary hormone even after mild TBI $(1,3)$.

Several mechanisms have been suggested for hypothalamic-pituitary dysfunction due to TBI including hypoxic insult or direct mechanical injury to the hypothalamus, pituitary stalk, or the pituitary gland; compression from hemorrhage, edema, or increased intracranial pressure; and vascular injury to the hypothalamus or the pituitary gland $(2,5,6)$. However, none of these mechanisms has been proven. Recent prospective clinical studies have demonstrated that pituitary function improves over time in a considerable number of patients, but it may also worsen rarely over the 1- and 3-year period after TBI (1, 3, 4). The possible 
mechanisms underlying the recovery and worsening of pituitary function remain to be clarified. However, the dynamic changes in pituitary function suggest that head trauma may trigger an ongoing process such as autoimmunity (4). A possible role of autoimmunity could be suggested by studies in animals that demonstrated naturally occurring IgG autoantibodies against dying neurons in the injured brain of adult rats following a cortical lesion (7) and autoreactive antibodies against neurons and basal lamina in the serum of rats submitted to experimental TBI (8). Although the antibodies against neurons have been demonstrated in injured animal studies, investigations regarding the occurrence of antipituitary antibodies (APAs) in patients with TBI are lacking in the literature. However, these antibodies have been detected in patients with selective idiopathic hypopituitarism, particularly in those with GH deficiency $(9,10)$ and in adults with autoimmune endocrine diseases (11-13).

In order to investigate whether autoimmune mechanisms could play a role in the pituitary dysfunction after TBI, we planned this study with the aim of investigating the presence of APA at the third year of TBI and evaluating the association between TBIinduced hypopituitarism and APA.

\section{Patients and methods}

Twenty-nine patients (25 males and 4 females; age $36.5 \pm 2.3$ years) who had completed a 3-year follow-up after TBI were included in the present study. The study was approved by the Local Committee on Ethics.

The level of consciousness of the patients was evaluated by the Glasgow Coma Scale as soon as the patient was admitted to the neurosurgery intensive care unit. A score of 13-15 is considered mild, 9-12 moderate, and $\leq 8$ severe TBI. Out of the 29,18 $(62.1 \%)$ patients had mild, $6(20.7 \%)$ had moderate, and $5(17.2 \%)$ had severe TBI. Initial computed tomography (CT) findings of the 29 patients were as follows: 12 had sub/epidural hemorrhage, 8 had cranial vault fracture, 6 had normal CT findings, 2 had severe brain swelling, and 1 had basal skull fracture. None of the patients had polytrauma (defined as two or more severe injuries in at least two areas of the body). Clinical status at the third year of TBI was assessed by the modified Rankin Scale (14) with the following grades: 0, no symptoms; 1 , no substantial disability; 2, slight disability; 3 , moderate disability; 4 , moderately severe disability; 5 , severe disability; and 6 , vegetative state.

None of the patients had history of any known pituitary disorder or autoimmune diseases. All the patients were not using any drug affecting hypothalamic-pituitary function. The cause of TBI was road traffic accidents in 18 patients and falls in 11 patients. Some of the data regarding the pituitary function of these patients have been recently published (4).
APAs and pituitary function were evaluated in all patients 3 years after TBI; moreover, APAs were tested also in sera of 60 age-/sex-matched normal controls.

\section{Evaluation of pituitary function by basal hormone levels and dynamic tests}

Basal hormone levels including free tri-iodothyronine $\left(\mathrm{fT}_{3}\right)$, free thyroxine $\left(\mathrm{fT}_{4}\right)$, thyrotrophin (TSH), prolactin, cortisol, adrenocorticotrophin (ACTH), follicle-stimulating hormone (FSH), luteinizing hormone (LH), insulin-like growth factor-I (IGF-I), GH, and total and free testosterone in males, or estradiol in females were measured. TSH and gonadotropin deficiencies were established as previously described (4). Briefly, TSH deficiency was defined by low serum $\mathrm{fT}_{4}$ levels $(<8 \mathrm{pg} / \mathrm{ml})$ without appropriate elevation in serum TSH. Gonadotropin deficiency was defined in males by basal and free testosterone levels below the normal range (total testosterone $<134 \mathrm{ng} / \mathrm{dl}$ and free testosterone $<11.5 \mathrm{pg} / \mathrm{ml}$ ) in the presence of normal or low gonadotropin levels. In premenopausal females, gonadotropin deficiency was defined by serum estradiol levels less than $11 \mathrm{pg} / \mathrm{ml}$ with an inappropriately low serum gonadotropin concentration. In postmenopausal women, the gonadotropin levels in the premenopausal range were used to diagnose the deficiency.

An ACTH deficiency was suggested when the basal cortisol level was below $7 \mu \mathrm{g} / \mathrm{dl}$, and it was confirmed by low-dose ACTH stimulation test. A low-dose ACTH stimulation test was performed by using $1 \mu \mathrm{g}$ tetracosartin (Synacthten, Novartis Pharma) i.v., and serum samples were obtained for cortisol measurement basally and at 30, 60, 90, and $120 \mathrm{~min}$. A peak cortisol level $<18 \mu \mathrm{g} / \mathrm{dl}$ was accepted as ACTH deficiency (15).

$\mathrm{GH}$ deficiency was investigated by the GH-releasing hormone $(\mathrm{GHRH})+\mathrm{GH}$ related peptide (GHRP)- 6 test in all patients. For the combined test, a peak value of $\leq 10 \mu \mathrm{g} / \mathrm{l}$ was accepted as GH deficiency, while a peak $>20 \mu \mathrm{g} / \mathrm{l}$ was considered as a normal response. GH peak values between 11 and $19 \mu \mathrm{g} / \mathrm{l}$ were considered as uncertain. After having basal sample at $-15 \mathrm{~min}$, the combined test i.v. bolus injection of $1 \mu \mathrm{g} / \mathrm{kg}$ GHRH (GH releasing factor (GRF) 1-29 $\mathrm{NH}_{2}$, Geref Serono, Madrid, Spain), immediately followed by an i.v. injection of $1 \mu \mathrm{g} / \mathrm{kg}$ GHRP-6 (His-DTrp-Ala-Trp-DPhe-Lys- $\mathrm{NH}_{2}$; Clinalfa, Laufelfinger, Switzerland), was administered at $0 \mathrm{~min}$, and further samples were obtained at 15, 30, $45,60,90$, and 120 min of injection (16).

We defined GH deficiency in the uncertain group $(\mathrm{GH}$ peak values between 11 and $19 \mu \mathrm{g} / \mathrm{l}$ after combined test) by performing glucagon stimulation test ( $1 \mathrm{mg}$ i.m. Glucagon; Novonordisk, Bagsvaerd, Denmark; with blood sampling for GH at baseline, 90, 120, 150, 180, 210 , and $240 \mathrm{~min}$ ). The subjects in uncertain group according to GHRH+GHRP-6 test were accepted as normal if the GH responses exceeded the cut-off value 
after glucagon test. To establish normal GH response to glucagon stimulation, the cut-off value was estimated from the $\mathrm{GH}$ responses of 22 healthy controls as previously described (17). Therefore, we took cut-off of $1.18 \mu \mathrm{g} / \mathrm{l}$ as a normal $\mathrm{GH}$ response after glucagon administration.

\section{APA evaluation}

APAs were investigated in 29 TBI patients 3 years after head trauma and in 60 age-/sex-matched normal controls by an indirect immunofluorescence method on the cryostat section of baboon pituitary gland supplied by Biosystem (Milan, Italy) s.r.l. as previously described (9). In particular, fluorescein isothiocyanateconjugated goat anti-human IgG sera was used to detect the presence of APA; the APAs were considered positive starting at the dilution of 1:8. Control group was recruited from volunteers who had no traffic accident and no previous hospitalization history due to head trauma. Additionally, if the controls declared any kind of simple head trauma including during childhood period, they were not included in the control group.

\section{Statistical analysis}

Statistical analysis was performed by using the SPSS 10.0 program. All the data were subjected to the KolmogorovSmirnov test for normality and are presented as mean \pm s.e.M. The differences between the groups were compared by unpaired $t$-test, and not normally distributed two groups were compared by Mann-Whitney $U$ test. The categorical data were shown as percentages and compared with $\chi^{2}$-test. Odds ratio (OR) and 95\% confidence intervals $(\mathrm{CI})$ were calculated. $P<0 \cdot 05$ was considered statistically significant. In addition, Spearman's correlation analysis was done to determine whether significant correlations existed between chosen variables.

\section{Results}

The behavior of APA in all patients and normal controls is depicted in Fig. 1A, whereas immunostaining of APApositive and APA-negative sera is depicted in Fig. 1B. APAs were detected in 13 out of the 29 TBI patients $(44.8 \%)$, but in none of normal controls. Among the 13

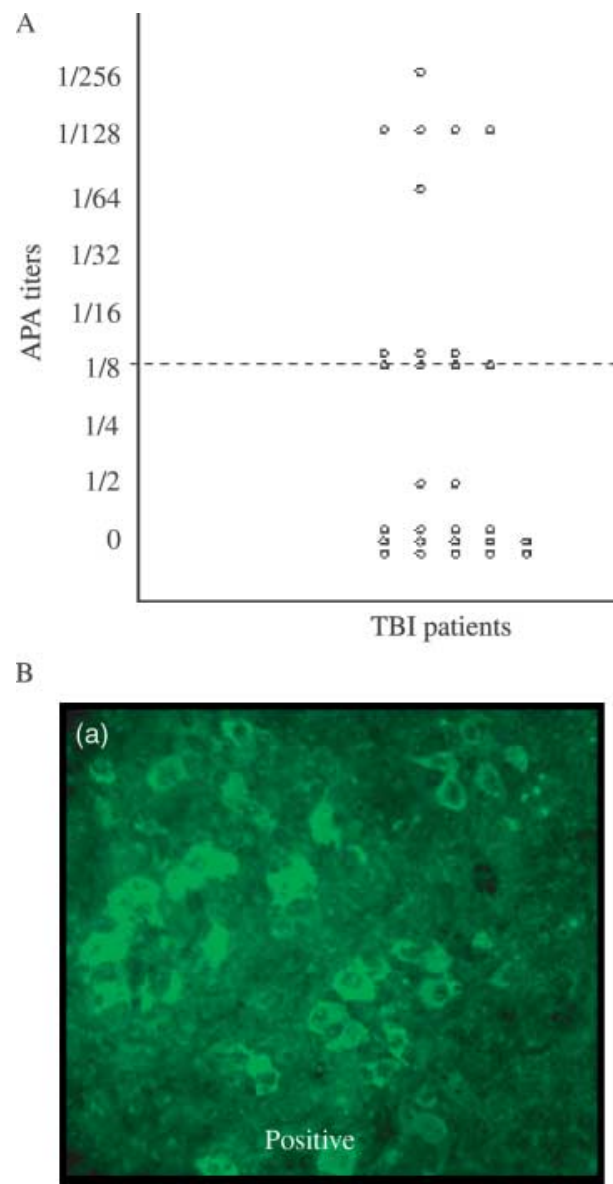

Figure 1 (A) Behavior of antipituitary antibodies (APAs) in patients with TBI and in 60 normal controls. (B) Serum sample positive for antipituitary antibodies detected by immunofluorescence in (a) a TBI patient in comparison with (b) a negative control serum. 
APA-positive patients, 7 (53.8\%) were weakly positive (titer $=1 / 8)$, while 6 of them $(46.2 \%)$ were strongly positive (titer ranging from 1/64 to 1/256).

Clinical characteristics, pituitary function, and individual APA titers in all patients are shown in Table 1. Out of the 29 patients, $8(27.6 \%)$ had pituitary dysfunction, particularly isolated GH deficiency. Pituitary dysfunction was evidenced in 6 (isolated $\mathrm{GH}$ deficiency in five and ACTH deficiency in one) out of the 13 APA-positive patients $(46.2 \%)$ and only in 2 out of the 16 APA-negative patients (12.5\%). Interestingly, all patients strongly positive for APA showed pituitary dysfunction, but none of those patients weakly positive for APA had pituitary dysfunction (Table 1).

The comparison of pituitary dysfunction development after TBI between APA-positive $(n=13)$ and APAnegative $(n=16)$ patients showed that pituitary dysfunction was significantly higher in APA-positive patients $(46.2 \%)$ when compared with APA-negative ones $(12.5 \%)(P=0.04)$. The corresponding OR was 2.25 (95\% CI 1.1-4.6), showing that the relative chance of having pituitary dysfunction after TBI increased 2.25-fold when the patient was positive for APA. There were no significant associations between the clinical parameters (initial CT findings and modified Rankin scale) and the presence of pituitary dysfunction and APA (data not shown).
Comparing the measured hormone levels between APA-positive group and APA-negative group, mean total testosterone, free testosterone, $\mathrm{GH}$, GH peak after GHRH + GHRP-6 test, and IGF-I levels were significantly lower in APA-positive patients $(P<0.05$; Table 2$)$. Performing a correlation analysis, there was a significant positive correlation $(r=0.74, P=0.004)$ between APA titer ratio (higher titer ratio means low APA titer) and peak $\mathrm{GH}$ response to GHRH + GHRP- 6 test, showing that high APA titers were associated with low GH response to GHRH+GHRP-6 test.

\section{Discussion}

This study demonstrates for the first time the presence of APA in TBI patients 3 years after head trauma. Moreover, present investigation provides preliminary evidence that APAs are associated with the development of TBI-induced pituitary dysfunction.

After TBI, 20-50\% of patients have been reported to have some degrees of pituitary dysfunction, and isolated pituitary hormone deficiencies are more frequent than multiple hormone deficiencies (1-4). To date, only five prospective studies following the patients over 12 months after TBI have been reported. These studies showed that during the 12-month period, pituitary

Table 1 Individual evaluation of pituitary hormone deficiencies at 3 years after traumatic brain injury (TBI), and the antipituitary antibody (APA) titers in the 29 patients investigated.

\begin{tabular}{|c|c|c|c|c|c|c|}
\hline $\mathbf{N}$ & GCS & TSH & FSH/LH & АСТH & GH & APA titer \\
\hline 1 & Mild & $\mathrm{N}$ & $\mathrm{N}$ & $\mathrm{N}$ & $\mathrm{N}$ & $1: 8$ \\
\hline 2 & Mild & $\mathrm{N}$ & $\mathrm{N}$ & $\mathrm{N}$ & $\mathrm{N}$ & Negative \\
\hline 3 & Mild & $\mathrm{N}$ & $\mathrm{N}$ & $\mathrm{N}$ & $\mathrm{N}$ & Negative \\
\hline 4 & Mild & $\mathrm{N}$ & $\mathrm{N}$ & $\mathrm{N}$ & D & $1: 128$ \\
\hline 5 & Mild & $\mathrm{N}$ & $\mathrm{N}$ & $\mathrm{N}$ & $\mathrm{N}$ & Negative \\
\hline 6 & Mild & $\mathrm{N}$ & $\mathrm{N}$ & $\mathrm{N}$ & $\mathrm{N}$ & Negative \\
\hline 7 & Mild & $\mathrm{N}$ & $\mathrm{N}$ & $\mathrm{N}$ & $\mathrm{N}$ & $1: 8$ \\
\hline 8 & Mild & $\mathrm{N}$ & $\mathrm{N}$ & $\mathrm{N}$ & $\mathrm{N}$ & Negative \\
\hline 9 & Mild & $\mathrm{N}$ & $\mathrm{N}$ & $\mathrm{N}$ & $\mathrm{N}$ & Negative \\
\hline 10 & Mild & $\mathrm{N}$ & $\mathrm{N}$ & $\mathrm{D}$ & $\mathrm{N}$ & $1: 64$ \\
\hline 11 & Mild & $\mathrm{N}$ & $\mathrm{N}$ & $\mathrm{N}$ & $\mathrm{N}$ & Negative \\
\hline 12 & Mild & $\mathrm{N}$ & $\mathrm{N}$ & $\mathrm{N}$ & $\mathrm{N}$ & $1: 8$ \\
\hline 13 & Mild & $\mathrm{N}$ & $\mathrm{N}$ & $\mathrm{N}$ & $\mathrm{N}$ & Negative \\
\hline 14 & Mild & $\mathrm{N}$ & $\mathrm{N}$ & $\mathrm{N}$ & $\mathrm{N}$ & Negative \\
\hline 15 & Mild & $\mathrm{N}$ & $\mathrm{N}$ & $\mathrm{N}$ & $\mathrm{N}$ & $1: 8$ \\
\hline 16 & Mild & $\mathrm{N}$ & $\mathrm{N}$ & $\mathrm{N}$ & $\mathrm{N}$ & Negative \\
\hline 17 & Mild & $\mathrm{N}$ & $\mathrm{N}$ & $\mathrm{N}$ & D & $1: 256$ \\
\hline 18 & Mild & $\mathrm{N}$ & $\mathrm{N}$ & $\mathrm{N}$ & $\mathrm{N}$ & Negative \\
\hline 19 & Moderate & $\mathrm{N}$ & $\mathrm{N}$ & $\mathrm{N}$ & $\mathrm{N}$ & $1: 8$ \\
\hline 20 & Moderate & $\mathrm{N}$ & $\mathrm{N}$ & $\mathrm{N}$ & D & Negative \\
\hline 21 & Moderate & $\mathrm{N}$ & $\mathrm{N}$ & $\mathrm{N}$ & D & $1: 128$ \\
\hline 22 & Moderate & $\mathrm{N}$ & $\mathrm{N}$ & $\mathrm{N}$ & $\mathrm{N}$ & Negative \\
\hline 23 & Moderate & $\mathrm{N}$ & $\mathrm{N}$ & $\mathrm{N}$ & $\mathrm{N}$ & $1: 8$ \\
\hline 24 & Moderate & $\mathrm{N}$ & $\mathrm{N}$ & $\mathrm{N}$ & $\mathrm{N}$ & Negative \\
\hline 25 & Severe & $\mathrm{N}$ & $\mathrm{N}$ & D & $\mathrm{N}$ & Negative \\
\hline 26 & Severe & $\mathrm{N}$ & $\mathrm{N}$ & $\mathrm{N}$ & D & $1: 128$ \\
\hline 27 & Severe & $\mathrm{N}$ & $\mathrm{N}$ & $\mathrm{N}$ & $\mathrm{N}$ & $1: 8$ \\
\hline 28 & Severe & $\mathrm{N}$ & $\mathrm{N}$ & $\mathrm{N}$ & $\mathrm{N}$ & Negative \\
\hline 29 & Severe & $\mathrm{N}$ & $\mathrm{N}$ & $\mathrm{N}$ & D & $1: 128$ \\
\hline
\end{tabular}

GCS, Glasgow Coma Scale on admission; N, normal pituitary hormone; D, deficient pituitary hormone. 
Table 2 Comparison of age, body mass index (BMI), and hormone levels in traumatic brain injury (TBI) patients with antipituitary antibody (APA) positive and APA negative.

\begin{tabular}{|c|c|c|c|}
\hline & $\begin{array}{c}\text { APA-positive } \\
\text { patients }(n=13)\end{array}$ & $\begin{array}{c}\text { APA-negative } \\
\text { patients }(n=16)\end{array}$ & $P$ \\
\hline Age (year) & $38.1 \pm 2.6$ & $35.2 \pm 3.7$ & NS \\
\hline BMI $\left(\mathrm{kg} / \mathrm{m}^{2}\right)$ & $25.8 \pm 1.0$ & $23.8 \pm 0.9$ & NS \\
\hline $\begin{array}{l}\text { Modified Rankin } \\
\text { Scale }\end{array}$ & $1.8 \pm 0.3$ & $1.1 \pm 0.3$ & NS \\
\hline $\mathrm{ST}_{3}(\mathrm{pg} / \mathrm{ml})$ & $2.5+0.1$ & $2.3+0.1$ & NS \\
\hline $\mathrm{ST}_{4}(\mathrm{pg} / \mathrm{ml})$ & $11.4 \pm 0.6$ & $11.3 \pm 0.4$ & NS \\
\hline $\mathrm{TSH}(\mathrm{mlU} / \mathrm{ml})$ & $2.2 \pm 0.6$ & $1.6 \pm 0.2$ & NS \\
\hline Prolactin (ng/ml) & $9.3 \pm 1.5$ & $8.3 \pm 0.8$ & NS \\
\hline $\mathrm{FSH}(\mathrm{mlU} / \mathrm{ml})$ & $5.9 \pm 1.2$ & $5.6 \pm 0.6$ & NS \\
\hline $\mathrm{LH}(\mathrm{mlU} / \mathrm{ml})$ & $5.0 \pm 1.5$ & $4.6 \pm 0.3$ & NS \\
\hline ACTH (pg/ml) & $11.2 \pm 2.7$ & $9.2 \pm 2.3$ & NS \\
\hline Cortisol ( $\mu \mathrm{g} / \mathrm{dl})$ & $13.4 \pm 1.6$ & $13.5 \pm 1.1$ & NS \\
\hline $\begin{array}{l}\text { Total testosterone } \\
(\mathrm{ng} / \mathrm{dl})^{\mathrm{a}}\end{array}$ & $528 \pm 58$ & $707 \pm 52$ & $0.03^{*}$ \\
\hline $\begin{array}{l}\text { Free testosterone } \\
\qquad(\mathrm{ng} / \mathrm{ml})^{\mathrm{a}}\end{array}$ & $14.9 \pm 1.4$ & $20.4 \pm 1.8$ & $0.04^{*}$ \\
\hline $\mathrm{GH}(\mu \mathrm{g} / \mathrm{l})$ & $0.34 \pm 0.21$ & $2.8 \pm 1.1$ & $0.003^{*}$ \\
\hline IGF-I (ng/ml) & $212 \pm 31$ & $326 \pm 39$ & $0.04^{*}$ \\
\hline $\begin{array}{l}\text { Peak GH level } \\
\text { ( } \mu \mathrm{g} / \mathrm{l}) \text { after GHRH+ } \\
\text { GHRP-6 test }\end{array}$ & $27.7 \pm 8.3$ & $61.6 \pm 10.9$ & $0.01^{*}$ \\
\hline
\end{tabular}

Mean \pm S.E.M.; ${ }^{\star} P<0.05$; NS, not significant.

${ }^{a}$ Total and free testosterone levels were measured only in males.

function may improve in the majority of the patients, but also may worsen in some of them $(1,3,18-20)$. Recently, in the first 3-year prospective follow-up after TBI, we have demonstrated that pituitary function may improve overtime in a considerable number of patients but more rarely a worsening or new onset of isolated hypopituitarism may appear over 3 years (4). The possible mechanisms underlying the recovery of pituitary function of the worsening and the new onset cases of pituitary dysfunction remain to be clarified. A possible responsibility of autoimmune process involving the hypothalamic-pituitary region triggered by head trauma might be suggested by studies in animals. In an experimental study, naturally occurring IgG autoantibodies against dying neurons in the injured brain have been detected in adult rats following a cortical lesion, and it has been proposed that autoantibody binding may participate in the phagocytosis and removal of the injured neurons (7). Furthermore, autoreactive antibodies against neurons and basal lamina have been found in serum following experimental TBI in rats. The authors concluded that the presence of autoreactive antibodies against neurons and basal lamina after TBI could play a pathogenic role in the delayed neuron degeneration (8). Even if studies in humans investigating the occurrence of APA in patients with TBI are lacking in the literature, these antibodies have been detected in patients with selective idiopathic hypopituitarism and in adults with autoimmune endocrine diseases $(9,11,13)$. It has been shown by double immunofluorescence using baboon pituitary gland and anti-sera to $\mathrm{GH}$ and $\mathrm{FSH} / \mathrm{LH}$ respectively that somatotrophs and gonadotrophs seem to be an early target of these antibodies in patients with idiopathic GH deficiency and idiopathic hypogonadotropic hypogonadism $(21,22)$. Moreover, the lack of data by International Standardization in evaluating APA suggests the necessity of further controlled studies to validate our assumption.

The first important point emerging from the present study is the detection of APA in $44.8 \%$ of TBI patients. There was a significant association between APA and hypopituitarism due to TBI (OR: 2.25, 95\% CI 1.1-4.6). Pituitary dysfunction development was significantly higher in APA-positive patients when compared with that of the APA-negative patients. Additionally, a strong result of this study is the presence of APA at high titer (titer 1/64-1/256) in all patients with pituitary dysfunction and the association of high APA titers and a low GH response to GHRH + GHRP-6 test, evidenced by a correlation analysis. The majority of our patients had mild TBI, which is a possible limitation of the study design. In a recent systematic review, it has been shown that pooled prevalences (14 studies and 1015 patients) of hypopituitarism with severe, moderate, and mild TBI were $35.3,10.9$, and $16.8 \%$ respectively (23). This finding implies that although the risk is lower than severe TBI patients, mild TBI patients also have substantial risk of hypopituitarism. Present results suggest that the activation of pituitary autoimmunity, as evidenced by the presence of APA at high titers, may have an impact on the development of pituitary dysfunction after TBI. This also seems to indicate that the evolution of pituitary function in these patients is correlated with APA titer. In fact, it has been shown that during the natural course of lymphocytic hypophysitis, APA could sometimes spontaneously disappear and spontaneous partial or total pituitary recovery and/or mass resolution can occur $(11,21)$. The presence of selective hypopituitarism in the two APA-negative patients requires a discussion. Generally, in patients after moderate and severe TBI, necrotic, ischemic, and hypoxic changes could be present not only at pituitary but also at hypothalamic level $(2,24)$; GHRH and corticotrophin-releasing hormone neurons could be highly vulnerable to injury in these cases $(24,25)$. With this in mind, it is tempting to speculate that head trauma may trigger an ongoing cascade of vascular and histopathological alterations involving mediators of inflammatory process, thus favoring the immune system activation that can contribute to late pituitary dysfunction. In particular, generally in patients with TBI, as a result of the primary injury, brain edema and circulatory disturbance may occur (26-28). Inflammatory mediators (cytokines, in particular interleukin (IL) 6 , free radicals, amino acids, and nitric oxide) may lead to accelerated neuronal-cell necrosis $(27,29)$. The infundibular hypothalamic-pituitary structure due to its peculiar anatomical and vascular characteristics 
may be very vulnerable to these necrotic, ischemic, and hypoxic changes present after TBI (25). In contrast to present findings, APAs were found to be negative in pituitary damage secondary to surgery for pituitary and parasellar tumors (9). However, $50 \%$ of these 14 patients developed panhypopituitarism after surgery, and removal of the potential source of antigens might be one possible explanation of the absence of APA. The release of sequestered pituitary antigens from necrotic pituitary system with the subsequent triggering of pituitary autoimmunity could lead to late post-traumatic hypopituitarism. At this time, it is not possible to establish whether APA could be directly involved in the impairment of the pituitary cells and may contribute to development of pituitary dysfunction, or rather if they are good markers of this triggering of pituitary autoimmunity in patients with hypopituitarism after TBI. To this purpose, longitudinal studies on a more numerous cohort of TBI patients are needed to ascertain the true role of these antibodies.

In conclusion, our results suggest that APAs are present in most of the TBI patients 3 years after head trauma, and they may be associated with the development of TBI-induced pituitary dysfunction. This suggests that autoimmunity may contribute to the development of TBI-induced hypopituitarism. Moreover, longitudinal studies with high numbers of patients are needed to clarify the predictive value of APA as a marker of pituitary dysfunction and the possible clinical implications. The presence of the association between APA and TBI-induced hypopituitarism may provide a new point of view in this field and promote further clinical and experimental studies.

\section{Acknowledgements}

We gratefully acknowledge Mrs Nilgün Yildirim and Mrs Songul Atakli for their irreplaceable nursing assistance.

\section{References}

1 Aimaretti G, Ambrosio MR, Di Somma C, Gasperi M, Cannavo S, Scaroni C, Fusco A, Del Monte P, De Menis E, Faustini-Fustini M, Grimaldi F, Logoluso F, Razzore P, Rovere S, Benvenga S, degli Uberti EC, De Marinis L, Lombardi G, Mantero F, Martino E, Giordano G \& Ghigo E. Residual pituitary function after brain injury-induced hypopituitarism: a prospective 12-month study. Journal of Clinical Endocrinology and Metabolism 20059 6085-6092.

2 Kelly DF, Gonzalo IT, Cohan P, Berman N, Swerdloff R \& Wang C. Hypopituitarism following traumatic brain injury and aneurysmal subarachnoid hemorrhage: a preliminary report. Journal of Neurosurgery 200093 743-752.

3 Tanriverdi F, Senyurek H, Unluhizarci K, Selcuklu A, Casanueva FF \& Kelestimur F. High risk of hypopituitarism after traumatic brain injury: a prospective investigation of anterior pituitary function in the acute phase and 12 months after trauma. Journal of Clinical Endocrinology and Metabolism $2006912105-2111$.
4 Tanriverdi F, Ulutanaca H, Unluhizarci K, Selcuklu A, Casanueva FF \& Kelestimur F. Three years prospective investigation of anterior pituitary function after traumatic brain injury: a pilot study. Clinical Endocrinology 200768 573-579.

5 Kelestimur F. Chronic trauma in sports as a cause of hypopituitarism. Pituitary 20058 259-262.

6 Yuan $\mathrm{XQ} \&$ Wade CE. Neuroendocrine abnormalities in patients with traumatic brain injury. Frontiers in Neuroendocrinology 1991 12 209-230.

7 Stein TD, Fedynyshyn JP \& Kalil RE. Circulating autoantibodies recognize and bind dying neurons following injury to the brain. Journal of Neuropathology and Experimental Neurology 200261 1100-1108.

8 Rudehill S, Muhallab S, Wennersten A, von Gertten C, Al Nimer F, Sandberg-Nordqvist AC, Holmin S \& Mathiesen T. Autoreactive antibodies against neurons and basal lamina found in serum following experimental brain contusion in rats. Acta Neurochirurgica $2006 \mathbf{1 4 8} 199-205$.

9 De Bellis A, Bizzarro A, Conte M, Perrino S, Coronella C, Solimeno S, Sinisi AM, Stile LA, Pisano G \& Bellastella A. Antipituitary antibodies in adults with apparently idiopathic growth hormone deficiency and in adults with autoimmune endocrine diseases. Journal of Clinical Endocrinology and Metabolism 200388 650-654.

10 De Bellis A, Salerno M, Conte M, Coronella C, Tirelli G, Battaglia M, Esposito V, Ruocco G, Bellastella G, Bizzarro A \& Bellastella A. Antipituitary antibodies recognizing growth hormone (GH)-producing cells in children with idiopathic GH deficiency and in children with idiopathic short stature. Journal of Clinical Endocrinology and Metabolism 200691 2484-2489.

11 Caturegli P, Newschaffer C, Olivi A, Pomper MG, Burger PC \& Rose NR. Autoimmune hypophysitis. Endocrine Reviews 200526 599-614.

12 De Bellis A, Bizzarro A, Perrino S, Coronella C, Conte M, Pasquali D, Sinisi AA, Betterle C \& Bellastella A. Characterization of antipituitary antibodies targeting pituitary hormonesecreting cells in idiopathic growth hormone deficiency and autoimmune endocrine diseases. Clinical Endocrinology 2005 63 45-49.

13 Manetti L, Lupi I, Morselli LL, Albertini S, Cosottini M, Grasso L, Genovesi M, Pinna G, Mariotti S, Bogazzi F, Bartalena L \& Martino E. Prevalence and functional significance of antipituitary antibodies in patients with autoimmune and non-autoimmune thyroid diseases. Journal of Clinical Endocrinology and Metabolism $2007922176-2181$.

14 van Swieten JC, Koudstaal PJ, Visser MC, Schouten HJ \& van Gijn J. Interobserver agreement for the assessment of handicap in stroke patients. Stroke $198819604-607$.

15 Dickstein G, Shechner C, Nicholson WE, Rosner I, Shen-Orr Z, Adawi F \& Lahav M. Adrenocorticotropin stimulation test: effects of basal cortisol level, time of day, and suggested new sensitive low dose test. Journal of Clinical Endocrinology and Metabolism 199172 773-778.

16 Popovic V, Leal A, Micic D, Koppeschaar HP, Torres E, Paramo C, Obradovic S, Dieguez C \& Casanueva FF. GH-releasing hormone and $\mathrm{GH}$-releasing peptide- 6 for diagnostic testing in GH-deficient adults. Lancet $20003561137-1142$.

17 Tanriverdi F, Unluhizarci K, Coksevim B, Selcuklu A, Casanueva FF \& Kelestimur F. Kickboxing sport as a new cause of traumatic brain injury-mediated hypopituitarism. Clinical Endocrinology $200766360-366$.

18 Agha A, Phillips J, O'Kelly P, Tormey W \& Thompson CJ. The natural history of post-traumatic hypopituitarism: implications for assessment and treatment. American Journal of Medicine 2005118 1416e1-1416e7.

19 Klose M, Juul A, Struck J, Morgenthaler NG, Kosteljanetz M \& Feldt-Rasmussen U. Acute and long-term pituitary insufficiency in traumatic brain injury: a prospective single-centre study. Clinical Endocrinology 200767 598-606. 
20 Schneider HJ, Schneider M, Saller B, Petersenn S, Uhr M, Husemann B, von Rosen F \& Stalla GK. Prevalence of anterior pituitary insufficiency 3 and 12 months after traumatic brain injury. European Journal of Endocrinology 2006 154 259-265.

21 De Bellis A, Bizzarro A \& Bellastella A. Pituitary antibodies and lymphocytic hypophysitis. Best Practice and Research. Clinical Endocrinology and Metabolism $20051967-84$.

22 De Bellis A, Sinisi AA, Conte M, Coronella C, Bellastella G, Esposito D, Pasquali D, Ruocco G, Bizzarro A \& Bellastella A. Antipituitary antibodies against gonadotropin-secreting cells in adult male patients with apparently idiopathic hypogonadotropic hypogonadism. Journal of Clinical Endocrinology and Metabolism $200792604-607$.

23 Schneider HJ, Kreitschmann-Andermahr I, Ghigo E, Stalla GK \& Agha A. Hypothalamopituitary dysfunction following traumatic brain injury and aneurysmal subarachnoid hemorrhage: a systematic review. Journal of the American Medical Association 2007298 1429-1438.

24 Ferriero DM. Neonatal brain injury. New England Journal of Medicine 2004351 1985-1995.
25 Popovic V. GH deficiency as the most common pituitary defect after TBI: clinical implications. Pituitary 20058 239-243.

26 Bondanelli M, Ambrosio MR, Zatelli MC, De Marinis L \& degli Uberti EC. Hypopituitarism after traumatic brain injury. European Journal of Endocrinology 2005152 679-691.

27 Gaetz M. The neurophysiology of brain injury. Clinical Neurophysiology 2004115 4-18.

28 Greenwald BD, Burnett DM \& Miller MA. Congenital and acquired brain injury. 1. Brain injury: epidemiology and pathophysiology. Archives of Physical Medicine and Rehabilitation $2003 \mathbf{8 4}$ S3-S7.

29 Gionis D, Ilias I, Moustaki M, Mantzos E, Papadatos I, Koutras DA \& Mastorakos G. Hypothalamic-pituitary-adrenal axis and interleukin- 6 activity in children with head trauma and syndrome of inappropriate secretion of antidiuretic hormone. Journal of Pediatric Endocrinology and Metabolism 200316 49-54.

Received 21 April 2008

Accepted 28 April 2008 